\title{
ЕКОЛОГІЧНИЙ ПОДАТОК ТА ЕКОЛОГІЧНІ ВИДАТКИ МІСЦЕВИХ БЮДЖЕТІВ УКРАЇНИ
}

\section{ECOLOGICAL TAX AND ENVIRONMENTAL EXPENDITURES OF UKRAINIAN LOCAL BUDGETS}

\author{
Сучек Світлана Ігорівна \\ аспірант, \\ Волинський національний університет імені Лесі Українки \\ ORCID: https://orcid.org/0000-0001-7057-0314 \\ Suchek Svitlana \\ Lesya Ukrainka Volyn National University
}

\begin{abstract}
Стаття присвячена питанню екологічного оподаткування на рівні місцевих бюджетів та фрінансуванню ними природоохоронних заходів. Проаналізовано доходи місцевих бюджетів від екологічних платежів, вплив змін до Податкового та Бюджетного кодексу в частині екологічного оподаткування на обсяги відповідних надходжень до місцевих бюджетів. Співставлено видатки на природоохоронну діяльність 3 надходженнями від екологічного податку, проаналізовано структуру екологічного податку в розрізі видів екологічних платежів за видами забруднень, часту екологічного податку в загальній структурі доходів місцевих бюджетів. Окреслено ряд проблем на рівні місцевих бюджетів, що перешкоджають вирішенню екологічно важливих питань. Запропоновано шляхи збільшення надходжень від екологічного оподаткування, підвищення його ефективності та реалізації покладених на нього функцій.
\end{abstract}

Ключові слова: екологічний податок, доходи місцевих бюджетів, видатки місцевих бюджетів, децентралізація, місцеві фрінанси, «зелені» фрінанси.

Статья посвящена вопросу экологического налогообложения на уровне местных бюджетов и фринансированию ними природоохранных мероприятий. Проанализированы доходы местных бюджетов от экологических платежей, влияние изменений в Налоговый и Бюджетный кодекс в части экологического налогообложения на объемы соответствующих поступлений в местные бюджеты. Сопоставлены расходы на природоохранную деятельность с поступлениями от экологического налога, проанализирована структура экологического налога в разрезе видов экологических платежей по видам загрязнений, долю экологического налога в общей структуре доходов местных бюджетов. Определен ряд проблем на уровне местных бюджетов, препятствующие решению экологически важных вопросов. Предложены пути увеличения поступлений от экологического налогообложения, повышение его эффективности и реализации возложенных на него функций.

ключевые слова: экологический налог, доходы местных бюджетов, расходы местных бюджетов, децентрализация, местные фринансы, «зеленые» фринансы.

The article is devoted to the issue of environmental taxation at the level of local budgets and their financing of environmental measures. The environmental issue is key on a global scale. Regardless of the level of economic development, each of the countries notes the importance of solving it. Like each of the world-class problems, the problem of the improper state of the environment as a result of human economic activity consists of problems at the level of specific production, plant, local reservoir, landfill. The revenues of local budgets from environmental payments, the impact of changes to the Tax and Budget Code in terms of environmental taxation on the amount of corresponding revenues to local budgets are analyzed. Expenditures on environmental activities are compared with revenues from the environmental tax, the structure of the environmental tax is analyzed in terms of types of environmental payments by type of pollution, the frequency of environmental tax in the overall structure of local budget revenues. A number of problems at the level of local budgets that hinder the solution of ecologically important issues are outlined. Ways to increase revenues from environmental taxation, increase its efficiency and implement the functions assigned to it have been proposed. The conclusion is made about the need to change the proportions of the distribution of environmental tax between the State and local budgets, return the carbon tax to the list of those distributed between the State and local budgets, increase environmental tax rates for all types of environmental pollution and the need to credit all accumulated environmental tax. to a special fund or trust fund. Given the severity of the topic of ecology for Ukraine, a real assessment of revenues in terms of types of environmental tax allowed us to 
assess their role in the formation of income that could potentially be used for environmental activities. Comparing the amounts of revenues from environmental taxation and expenditures on environmental activities, there is a noticeable imbalance in their ratio, which indicates the need to reconsider the approach to planning environmental measures in amounts commensurate with revenues from environmentally harmful activities.

Keywords: environmental tax, local budget revenues, local budget expenditures, decentralization, local finances, "green" finances.

Постановка проблеми. Екологічне питання $€$ одним 3 таких, що повинні бути вирішені людством найближчим часом. Зважаючи на те, що стан довкілля погіршує саме промислова діяльність людства, влив на поведінку забруднювачів у всьому світі здійснюється переважно через економічні важелі. Для нашої країни основним важелем $€$ екологічне оподаткування. Метою дослідження $€$ визначення ефрективності екологічного оподаткування на місцевому рівні.

Аналіз досліджень і публікацій. Питання екологічного оподаткування вцілому та на місцевому рівні зокрема є предметом досліджень багатьох науковців. Теоретичною і методологічною основою послужили праці вітчизняних вчених: О. Бойко, І. Варламова, П. Екінс, М. Карлін, О. Семерак, А. Слобожан та ін.

Формулювання цілей статті. Основною метою дослідження $є$ виявлення перешкод та шляхів їх усунення для ефрективного фрункціонування екологічного оподаткування як інструменту покращення екологічного ситуації.

Виклад основного матеріалу дослідження. Відповідно до Бюджетного кодексу України частина коштів отриманих від екологічного податку зараховується до місцевих бюджетів - 55 \% податку що справляється за скиди забруднюючих речовин безпосередньо у водні об'єкти, за розміщення відходів у спеціально відведених для цього місцях чи на об'єктах, крім розміщення окремих видів відходів як вторинної сировини, за викиди в атмоссрерне повітря забруднюючих речо- вин стаціонарними джерелами забруднення (за винятком викидів в атмосорерне повітря двоокису вуглецю), з них:

$-25 \%$ до бюджетів місцевого самоврядування (крім бюджетів міст Києва та Севастополя);

- 30\% до бюджетів обласних та Автономної Республіки Крим;

-55\% до бюджетів міста Київ та Севастополь.

Весь обсяг надходжень від екологічного податку, що надходять до місцевих бюджетів спрямовуються до спеціального фронду. Відповідно, передбачено, що отримані кошти мають конкретне призначення, а отже будуть використані на проведення природоохоронних заходів. Тож, ми провели аналіз надходжень коштів від екологічного податку до місцевих бюджетів в період 2016-2020 роки для оцінки достатності отриманих ресурсів для фрінансування природоохоронної діяльності.

Надходження екологічного податку до місцевих бюджетів у період 2016-2020 рр. мають тенденцію до зменшення. У 2017 році надходження зменшили на 390 млн грн в порівнянні з 2016 роком, у 2018 - на 835 млн грн менше, ніж у 2017. Незначній приріст надходжень відбувся у 2019 році, місцеві бюджети отримали 2238190 693,23 грн, що на 93 млн грн більше, ніж у 2018. При тому у 2020 знову відбулось зменшення обсягів надходжень, цього разу на 147 млн грн.

Власне зменшення надходжень пояснюється змінами у Бюджетному кодексі України: до 2018 року включно, до місцевих бюджетів зараховувалось 80 відсотків екологіч-

Таблиця 1

Надходження екологічного податку до місцевих бюджетів Автономної Республіки Крим, областей, міст Києва та Севастополя протягом 2016-2020 років, млн грн

\begin{tabular}{|l|c|c|c|c|c|}
\hline \multicolumn{1}{|c|}{ Вид платежу } & $\mathbf{2 0 1 6}$ & $\mathbf{2 0 1 7}$ & $\mathbf{2 0 1 8}$ & $\mathbf{2 0 1 9}$ & $\mathbf{2 0 2 0}$ \\
\hline $\begin{array}{l}\text { Екологічний податок, який справляється за викиди } \\
\text { в атмосфрерне повітря забруднюючих речовин } \\
\text { стаціонарними джерелами забруднення }\end{array}$ & 2,50 & 2,05 & 1,41 & 1,46 & 1,32 \\
\hline $\begin{array}{l}\text { Надходження від скидів забруднюючих речовин } \\
\text { безпосередньо у водні об'єкти }\end{array}$ & 0,11 & 0,11 & 0,08 & 0,08 & 0,08 \\
\hline $\begin{array}{l}\text { Надходження від розміщення відходів у спеціально } \\
\text { відведених для цього місцях чи на об'єктах, крім } \\
\text { розміщення окремих видів відходів як вторинної } \\
\text { сировини }\end{array}$ & 0,74 & 0,81 & 0,63 & 0,68 & 0,68 \\
\hline Екологічний податок, всього & 3,36 & 2,97 & 2,14 & 2,23 & 2,09 \\
\hline
\end{tabular}


ного податку (крім екологічного податку, що справляється за утворення радіоактивних відходів (включаючи вже накопичені) та/або тимчасове зберігання радіоактивних відходів їх виробниками понад встановлений особливими умовами ліцензії строк, який зараховується до загального фонду державного бюджету у повному обсязі), а з 2019 - лише 55\%. При тому починаючи з 2019 року згідно із п. 161 ст. 29 Бюджетного кодексу України запроваджено особливий порядок розподілу коштів Податку за викиди забруднюючих речовин стаціонарними джерелами забруднення, який полягає у тому, що надходження податку в частині викидів двоокису вуглецю зараховуються до загального фонду державного бюджету у повному обсязі [1].

В умовах децентралізації в Україні передача до Державного бюджету надходжень від вуглецевого податку суперечить обраній стратегії і зменшує фрінансові можливості місцевих бюджетів. Єдине, що могло б пояснити таке рішення - це створення окремого цільового фонду, який має на меті акумулювати кошти для реалізації загальнодержавної програми декарбонізації економіки, проте кошти зараховуються до загального фронду і просто розчиняються в загальному числі надходжень, тож окрім як потребою в збільшенні дохідної частини Державного бюджету та відсутністю чіткої екологічної політики, подібне рішення пояснити неможливо.

Тож, на нашу думку в Бюджетному кодексі потрібно закріпити перерозподіл вуглецевого податку між бюджетами різних рівнів на користь місцевих бюджетів і створити цільові фронди на державному та місцевому рівнях для накопичення коштів, що в перспективі забезпечать фрінансування заходів, спрямованих на «озеленення» економіки.

Екологічний податок, який справляється за викиди в атмосферне повітря забруднюючих речовин стаціонарними джерелами забруднення показує синхронну з загальним обсягом надходжень від екологічного податку динаміку. Тож в кожному наступному році зменшується. I якщо порівняти надходження у 2020 році 3 2016, то ми бачимо зменшення майже вдвічі.

Надходження від скидів забруднюючих речовин безпосередньо у водні об'єкти у 2017 році мало незначний приріст відносно надходжень 2016 року (на 2 млн грн), та протягом наступних трьох років обсяг надходжень поступово зменшується: у 2018 році зменшення на 25\% відносно 2017 року, у 2019 та 2020 на 13\% відносно надходжень попереднього року. Проте зважаючи на незначний обсяг надходжень від такого виду екологічного платежу це не надто відображається на загальному обсязі надходжень.

Надходження від розміщення відходів у спеціально відведених для цього місцях чи на об'єктах, крім розміщення окремих видів відходів як вторинної сировини і порівнянні 3 екологічним податком, який справляється за викиди в атмоссрерне повітря забруднюючих речовин стаціонарними джерелами забруднення надходить у значно менших обсягах. Надходження не мають чітко тенденції ні до зростання, ні до зменшення. У 2016 році до місцевих бюджетів надійшло 748787 186,92 грн від справляння зазначеного виду екологічного податку, наступного року відбувся приріст надходжень на 62 млн грн; у 2018 році помітне зменшення - на майже 177 млн грн в порівнянні 32017 роком. У 2019 році знову відбувся приріст (на 55 млн грн), у 2020 надходження практично незмінні (незначне зменшення на 7,8 млн грн).

Аналізуючи структуру екологічного податку в місцевих бюджетах, бачимо, що найбільша частка припадає на екологічний податок, який справляється за викиди в атмосфрерне повітря забруднюючих речовин стаціонарними джерелами забруднення, навіть після того, як у 2019 році до місцевих бюджетів припинились надходження екологічного податку, який справляється за викиди в атмосфрерне повітря двоокису вуглецю стаціонарними джерелами забруднення. При тому частка зменшується $374,4 \%$ у 2017 році до $63,4 \%$.

Другий за обсягами вид екологічного платежу в структурі екологічного податку, що зараховується до місцевих бюджетів - від розміщення відходів у спеціально відведених для цього місцях чи на об'єктах, крім розміщення окремих видів відходів як вторинної сировини, його частка у період 2016-2020 рр. зростає з 22,2\% до 32,2\% і відбувається це виключно за рахунок зменшення надходжень екологічного податку за викиди в атмоссрерне повітря забруднюючих речовин стаціонарними джерелами забруднення.

Частка надходжень від скидів забруднюючих речовин безпосередньо у водні об'єкти змінюється несуттєво і знаходиться у діапазоні від 3,4 до 4,1\%.

В загальному обсязі доходів місцевих бюджетів на екологічний податок припадає незначний відсоток, в період 2016-2021 рр., найбільшим було значення 0,92\% у 2016 році, найменшим - 0,38\% - у 2018 році. 


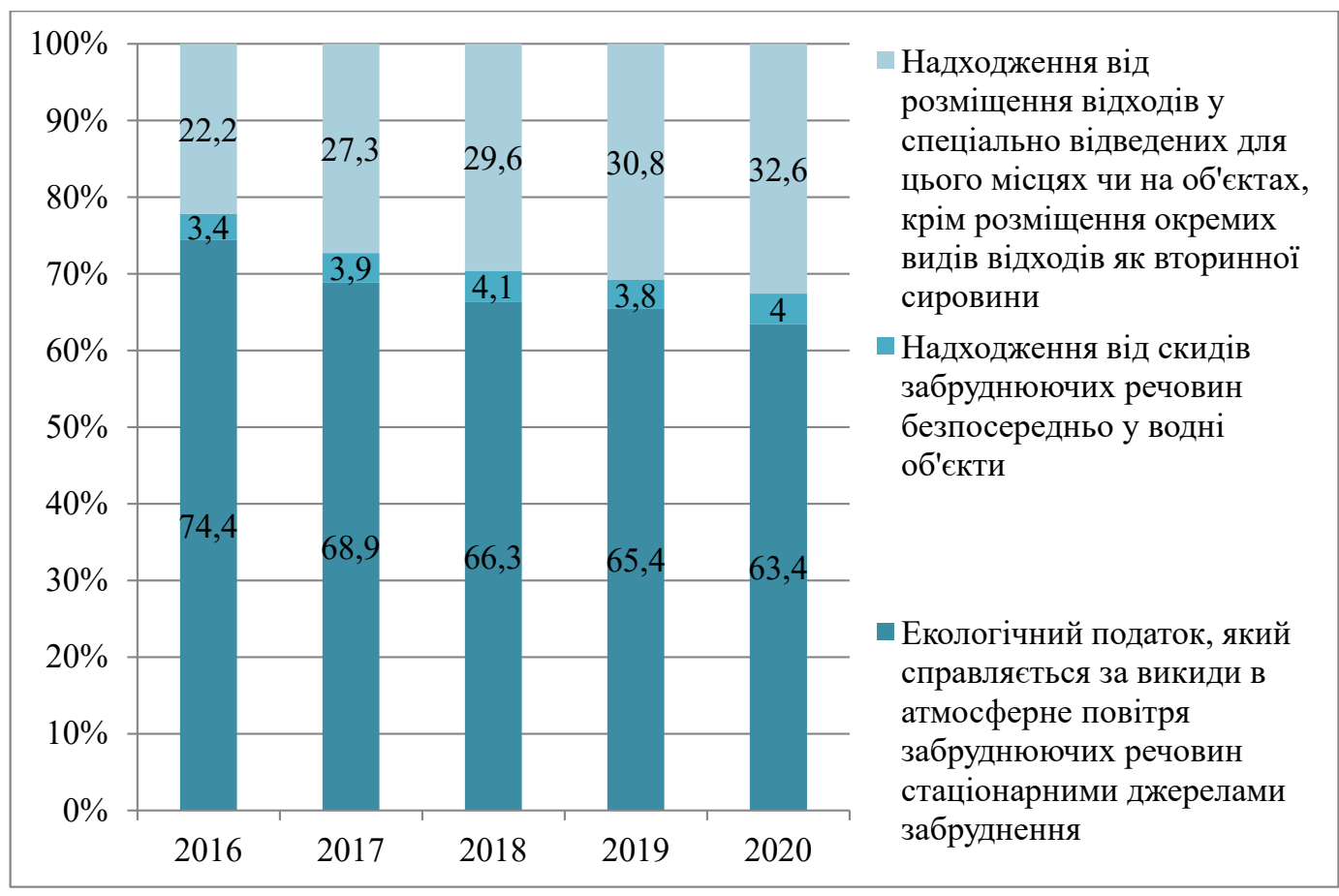

Рис. 1. Структура надходжень до місцевих бюджетів

Автономної Республіки Крим, областей, міст Києва та Севастополя екологічного податку протягом 2016-2020 років

Співвідношення надходжень від екологічного податку та видатків на охорону природного навколишнього середовища характеризується помітним дисбалансом. У 2016 році надходження більше ніж вдвічі перевищували видатки, а 2017 році на 14\%. Проте з 2018 року надходження на третину менші, ніж видатки. При тому, що кошти отримані від екологічного податку зараховуються до спецфонду і повинні мати цільове використання, у 2016-2017 році акумульовані кошти не були використані в повному обсязі на природоохоронну діяльність.
Натомість 32018 до 2020 роках на реалізацію природоохоронних заходів було залучено кошти у більшому обсязі, ніж податки, які держава отримала як компенсацію за нанесення шкоди довкіллю. При тому у країнах $€ С$ на захист довкілля витрачається близько 33\% надходжень від екологічного податку. Тож, з першого погляду здається, що Україна в питанні фрінансування природоохоронних заходів бере на себе більше зобов'язань в порівнянні з країнами $€ C$, проте $€$ важливе уточнення. У Європейському Союзі еколо-

Таблиця 2

Частка надходжень до місцевих бюджетів Автономної Республіки Крим,
областей, міст Києва та Севастополя екологічного податку
протягом 2016-2020 років в загальній структурі доходів, \%

\begin{tabular}{|l|c|c|c|c|c|}
\hline & $\mathbf{2 0 1 6}$ & $\mathbf{2 0 1 7}$ & $\mathbf{2 0 1 8}$ & $\mathbf{2 0 1 9}$ & $\mathbf{2 0 2 0}$ \\
\hline $\begin{array}{l}\text { Екологічний податок, який справляється за } \\
\text { викиди в атмоссрерне повітря забруднюючих } \\
\text { речовин стаціонарними джерелами забруднення } \\
\text { (за винятком викидів в атмосферне повітря } \\
\text { двоокису вуглецю) }\end{array}$ & 0,68 & 0,41 & 0,25 & 0,26 & 0,28 \\
\hline $\begin{array}{l}\text { Надходження від скидів забруднюючих речовин } \\
\text { безпосередньо у водні об'єкти }\end{array}$ & 0,03 & 0,02 & 0,02 & 0,02 & 0,02 \\
\hline $\begin{array}{l}\text { Надходження від розміщення відходів у } \\
\text { спеціально відведених для цього місцях чи } \\
\text { на об'єктах, крім розміщення окремих видів } \\
\text { відходів як вторинної сировини }\end{array}$ & 0,20 & 0,16 & 0,11 & 0,12 & 0,14 \\
\hline Екологічний податок (всього) & 0,92 & 0,59 & 0,38 & 0,40 & 0,44 \\
\hline
\end{tabular}




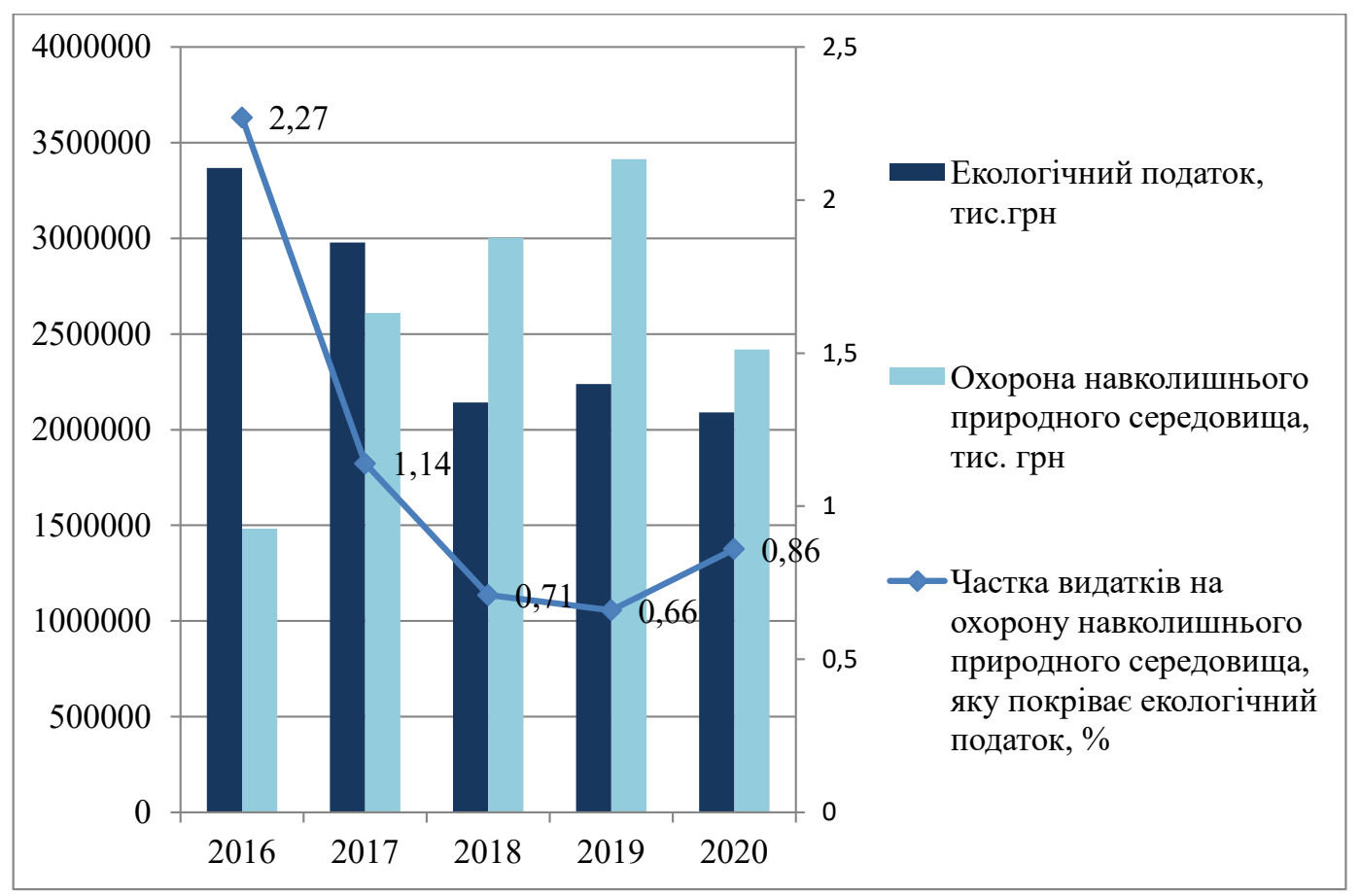

Рис. 2. Співвідношення надходжень від екологічного податку та видатків на охорону навколишнього середовища у місцевих бюджетах Автономної Республіки Крим, областей, міст Києва та Севастополя у 2016-2020 роках

гічний податок - поняття значно ширше від податку на забруднення, він включає 4 підгрупи платежів: енергетичні податки, транспортні податки, податки за забруднення навколишнього природного середовища та податки за користування природними ресурсами. I найбільший дохід бюджету приносять дві перші групи. В Україні частково існують вказані податки, проте вони не об'єднані в групу екологічних і кожен 3 них самобутній, хоча природа їх існування і функцій пов'язана із захистом навколишнього середовища.

Стосовно відмінності між еко-витратами українських та європейських бюджетів, головна різниця полягає в тому, що в Україні, як на місцевому, так і на державному рівні екологічний податок - це фріскальний інструмент на ряду із іншими податками, а в ЄС - це інструмент реалізації принципу «забруднювач платить» і джерело фрінансування переходу на «зелений» спосіб ведення господарської діяльності.

Ситуація також ускладнюється й тим, що з 2014 року в Україні відмовились від спеціального фронду держбюджету, куди зараховувались кошти від екоподатку, що сприяє нецільовому використанню коштів [3].

При тому й зарахування коштів до спеціального фронду місцевих бюджетів не гарантує покриття витрат на охорону навколиш- нього середовища за рахунок цих коштів, що ми бачимо на рисунку 3, 2016-2017 роки. Щодо 2018-2020 років, то фрінансування природоохоронних заходів відбувається в розмірі понад отримані місцевими бюджетами екологічні платежі, що ще раз підтверджує недостатність таких надходжень. Саме тому варто збільшити частку екоподатку, що зараховується до спецфондів місцевих бюджетів. щодо оптимальної пропорції, думки експертів дещо різняться. Ольга Бойко, Координатор Комітету промислової екології та сталого розвитку Європейська Бізнес Асоціація, пропонує 70\% екоподатку лишати на місцях, асоціація міст України, в особі О.В. Слобожана надіслала до Комітету Верховної ради з питань бюджету офріційний лист з пропозицією про збільшення для місцевих бюджетів відсотку зарахування екологічного податку з 25 до 30 відсотків за рахунок зменшення відсотку зарахування такого податку до державного фонду [5]. Разом з тим, для обласних бюджетів передбачається зростання відсотку зарахування податку 330 до 50 відсотків, а для міст Києва та Севастополя - з 55 до 80 відсотків. Депутати партії «Голос» зареєстрували законопроєкт, який залишає 80\% екологічного податку на місцях, і цей проєкт не єдиний в своєму роді [4]. Що об'єднує науковців, політичних діячів та практиків з управління бюджетами 
громад, так усвідомлення потреби в децентралізації еко-доходів бюджетів.

Висновок. На сьогодні ми маємо відсутність системи «самозабезпечення» природоохоронної діяльності. В країнах Європейського Союзу надходження від групи екологічних податків покривають витрати на природоохоронну діяльність, побудову «зеленої» економіки і частина коштів спрямовується на фрінансування державних витрат не пов'язаних 3 екологічно-економічною діяльністю. Поки екологічний податок не пов'язується при плануванні бюджету із природоохоронною діяльністю і фрункціонує поза системою координат планування видатків на охорону навколишнього середовища і не дає однозначного розуміння логіки його справляння і розподілу. Якщо йти від зворотного - від практики до теорії: на місцях реалізовується природо- охоронна діяльність фрінансування якої проходить із місцевих бюджетів в більшому обсязі, ніж ними отримано коштів від забруднювачів довкілля. Отже, на реалізацію цих заходів виділяються додаткові кошти, акумульовані з інших джерел доходів в т.ч. міжбюджетних трансфертів 3 Державного бюджету. Таким чином очевидною $€$ потреба в перегляді співвідношення розподілу екологічного податку на користь місцевих бюджетів аби скоротити кількість міжбюджетних транзакцій (оптимальним вважаю співвідношення $-20 \%$ до спецсронду Державного бюджету, 80\% - до місцевих). Одночасно з цим, зважаючи на незначні обсяги екологічного податку в загальній структурі доходів місцевих бюджетів та потребу в реалізації природоохоронних заходів знову постає питання збільшення тарифів за одиницю забруднюючих речовин.

\section{СПИСОК ВИКОРИСТАНИХ ДЖЕРЕЛ:}

1. Бюджетний кодекс України. URL: https://zakon.rada.gov.ua/laws/show/2456-17\#Text

2. Податковий кодекс України. URL: https://zakon.rada.gov.ua/laws/show/2755-17

3. Бойко О. 5 кроків у реформуванні екоподатку. 2020. URL: https://delo.ua/business/5-krokiv-u-reformuvanniekopodatku-368725/

4. Проект Закону про внесення змін до Бюджетного кодексу України щодо використання екологічного податку. 2021. URL: http://w1.c1.rada.gov.ua/pls/zweb2/webproc4_1?pf3511=71197

5. Слобожан А.В. До бюджетів громад потрібно зараховувати 50\% екологічного податку - АМУ. 2021. URL: https://www.auc.org.ua/novyna/do-byudzhetiv-gromad-potribno-zarahovuvaty-50-ekologichnogo-podatku-amu

6. Річний звіт про виконання Державного бюджету України за 2020 рік // Державна казначейська служба України. 2021. URL: https://www.treasury.gov.ua/ua/file-storage/richnij-zvit-pro-vikonannya-derzhavnogo-byudzhetuukrayini-za-2020-rik

7. Річний звіт про виконання Державного бюджету України за 2019 рік // Державна казначейська служба України. 2020. URL: https://www.treasury.gov.ua/ua/file-storage/richnij-zvit-pro-vikonannya-derzhavnogo-byudzhetuukrayini-za-2019-rik

8. Річний звіт про виконання Державного бюджету України за 2018 рік // Державна казначейська служба України. 2019. URL: https://www.treasury.gov.ua/ua/file-storage/richnij-zvit-pro-vikonannya-derzhavnogo-byudzhetuukrayini-za-2018-rik

9. Річний звіт про виконання Державного бюджету України за 2017 рік // Державна казначейська служба України. 2028. URL: https://www.treasury.gov.ua/ua/file-storage/richnij-zvit-pro-vikonannya-derzhavnogo-byudzhetuukrayini-za-2017-rik

10. Річний звіт про виконання Державного бюджету України за 2016 рік // Державна казначейська служба України. 2017. URL: https://www.treasury.gov.ua/ua/file-storage/richnij-zvit-pro-vikonannya-derzhavnogobyudzhetu-ukrayini-za-2016-rik

11. Карлін М.І. Зростання ролі фрінансово-екологічних інструментів у світовій та національних економіках: проблема вибору для України. Економічний часопис Східноєвропейського національного університету імені Лесі Українки. 2018. № 2. С. 117-124.

12. Остап Семерак. Підвищення екологічного податку - хороший стимул для підприємств проводити модернізацію шкідливих виробництв. Міністерство екології та природних ресурсів України. 2018. URL: https://menr.gov.ua/news/32014.html

13. Варламова І.С. Екологічне оподаткування як основа сталого розвитку національної економіки. Глобальні та національні проблеми економіки. 2015. URL: http://global-national.in.ua/archive/8-2015/170.pdf

14. Paul Ekins. Theory and Practice of Environmental Taxation. URL: http://www.greentaxreport.co.uk/ readchaptersonline/11-theory-and-practice-of-environmental-taxation?showall=1 


\section{REFERENCES:}

1. Budzhetnyi kodeks Ukrainy [Budget Code of Ukraine]. Available at: https://zakon.rada.gov.ua/laws/ show/2456-17\#Text

2. Podatkovyi kodeks Ukrainy [Tax Code of Ukraine]. Available at: https://zakon.rada.gov.ua/laws/show/2755-17

3. Boiko O. (2020) 5 krokiv u reformuvanni ekopodatku [5 steps in eco-tax reform]. delo.ua. Available at: https://delo.ua/business/5-krokiv-u-reformuvanni-ekopodatku-368725/

4. Proekt Zakonu pro vnesennia zmin do Biudzhetnoho kodeksu Ukrainy shchodo vykorystannia ekolohichnoho podatku [Draft Law on Amendments to the Budget Code of Ukraine on the Use of Environmental Tax]. Available at: http://w1.c1.rada.gov.ua/pls/zweb2/webproc4_1?pf3511=71197

5. Slobozhan A.V. (2021) Do biudzhetiv hromad potribno zarakhovuvaty 50\% ekolohichnoho podatku - AMU [Community budgets should include $50 \%$ of the environmental tax - ACU]. Available at: https://www.auc.org.ual novyna/do-byudzhetiv-gromad-potribno-zarahovuvaty-50-ekologichnogo-podatku-amu

6. Richnyi zvit pro vykonannia Derzhavnoho biudzhetu Ukrainy za 2020 rik [Annual report on the implementation of the State Budget of Ukraine for 2020]. Available at: https://www.treasury.gov.ua/ua/file-storage/richnij-zvit-provikonannya-derzhavnogo-byudzhetu-ukrayini-za-2020-rik

7. Richnyi zvit pro vykonannia Derzhavnoho biudzhetu Ukrainy za 2019 rik [Annual report on the implementation of the State Budget of Ukraine for 2019]. Available at: https://www.treasury.gov.ua/ua/file-storage/richnij-zvit-provikonannya-derzhavnogo-byudzhetu-ukrayini-za-2019-rik

8. Richnyi zvit pro vykonannia Derzhavnoho biudzhetu Ukrainy za 2018 rik [Annual report on the implementation of the State Budget of Ukraine for 2018]. Available at: https://www.treasury.gov.ua/ua/file-storage/richnij-zvit-provikonannya-derzhavnogo-byudzhetu-ukrayini-za-2018-rik

9. Richnyi zvit pro vykonannia Derzhavnoho biudzhetu Ukrainy za 2017 rik [Annual report on the implementation of the State Budget of Ukraine for 2017]. Available at: https://www.treasury.gov.ua/ua/file-storage/richnij-zvit-provikonannya-derzhavnogo-byudzhetu-ukrayini-za-2017-rik

10. Richnyi zvit pro vykonannia Derzhavnoho biudzhetu Ukrainy za 2016 rik [Annual report on the implementation of the State Budget of Ukraine for 2016]. Available at: https://www.treasury.gov.ua/ua/file-storage/richnij-zvit-provikonannya-derzhavnogo-byudzhetu-ukrayini-za-2016-rik

11.Karlin M.I. (2018) Zrostannia roli finansovo-ekolohichnykh instrumentiv u svitovii ta natsionalnykh ekonomikakh: problema vyboru dlia Ukrainy [Growing the role of financial and environmental instruments in world and national economies: the problem of choice for Ukraine]. Ekonomichnyi chasopys Skhidnoievropeiskoho natsionalnoho universytetu imeni Lesi Ukrainky - Economic Journal of the East European National University named after Lesia Ukrainka, 2, 117-124. (in Ukrainian)

12. Ostap Semerak (2018) Pidvyshchennia ekolohichnoho podatku - khoroshyi stymul dlia pidpryiemstv provodyty modernizatsiiu shkidlyvykh vyrobnytstv [Increasing the environmental tax is a good incentive for enterprises to modernize harmful industries]. Ministerstvo ekolohii ta pryrodnykh resursiv Ukrainy - Ministry of Ecology and Natural Resources of Ukraine. Available at: https://menr.gov.ua/news/32014.html (in Ukrainian)

13. Varlamova I.S. (2015) Ekolohichne opodatkuvannia yak osnova staloho rozvytku natsionalnoi ekonomiky [Ecological taxation as the basis of sustainable development of the national economy]. Hlobalni ta natsionalni problemy ekonomiky - Global and national problems of the economy. Available at: http://globalnational.in.ua/ archive/8-2015/170.pdf (in Ukrainian)

14.Paul Ekins (2006) Theory and Practice of Environmental Taxation. Available at: http://www.greentaxreport.co.uk/ read-chaptersonline/11-theory-and-practice-of-environmental-taxation?showall=1 